\title{
Funding Category
}

National Cancer Institute

\section{Source}

National Cancer Institute. Funding Category. NCI Thesaurus. Code C19335.

The specific subdivisions in a classification scheme of funding activities. 